\title{
Pendampingan Guru PAUD dalam Menyelenggarakan Sekolah Ramah Lingkungan
}

\author{
Peny Husna Handayani ${ }^{1}$, Gita Noveri Eza ${ }^{2}$, Suri Handayani Damanik ${ }^{3}$, \\ Vidya Dwi Amalia Zati ${ }^{4}$, Wan Nova Listia ${ }^{5}$ \\ Fakultas Ilmu Pendidikan, Universitas Negeri Medan \\ Jl. Willem Iskandar Medan, Sumatera Utara, Indonesia \\ e-mail: peny@unimed.ac.id
}

\begin{abstract}
Abstrak: Tujuan program pengabdian kepada masyarakat ini secara umum untuk meningkatkan keterampilan Guru PAUD dalam menyelenggarakan sekolah yang ramah lingkungan. Secara khusus kegiatan ini memberikan peningkatan terhadap Mitra yang meliputi; (1) peningkatan pemahaman Guru mengenai bahan praktikum yang berasal dari sampah; (2) peningkatan kemampuan Guru dalam mengidentifikasi jenis sampah yang bisa dijadikan sebagai bahan dalam membuat karya montase, kolase, dan mozaik; (3) peningkatan pengetahuan Guru untuk memahami pengertian, konsep, dan proses pembuatan karya montase, kolase, dan mozaik; dan (4) mengasah dan meningkatkan keterampilan Guru dalam membuat karya montase, kolase, dan mozaik. Metode pelaksanaan program pengabdian akan dilakukan secara berjenjang, berkesinambungan, dan komprehensif yang dilaksanakan melalui metode pendekatan. Pendekatan di sini dimaksudkan adalah perolehan informasi awal hingga proses kegiatan dilakukan dengan komunikasi secara langsung atau lewat alat komunikasi secara intensif dengan Mitra, sehingga pelaksanaan kegiatan dapat dilakukan secara terbimbing, dengan tujuan utama untuk meningkatkan keterampilan Guru TK Salsa dalam memanfaatkan sampah menjadi karya montase, kolase, dan mozaik. Untuk dapat dipamerkan dan di lihat oleh masyarakat sekolah khususnya murid-murid sekolah tersebut.
\end{abstract}

Kata kunci: Pendampingan guru PAUD, Sekolah ramah lingkungan

\section{PENDAHULUAN}

Lingkungan hidup yang baik dan sehat merupakan hak asasi dan hak konstitusional bagi setiap warga negara Indonesia. Oleh karena itu pemerintah, dan masyarakat berkewajiban untuk melakukan perlindungan dan pengelolaan lingkungan hidup. Namun pada kenyataannya saat ini telah terjadi kemunduran kualitas lingkungan hidup. Menurut hasil survei tahun 2013 yang dilakukan oleh Kementerian Lingkungan Hidup bekerja sama dengan Pusat Studi Kebijakan dan Kependudukan Universitas Gadjah Mada menunjukkan bahwa indeks perilaku masyarakat terhadap lingkungan masih rendah . Rendahnya kepedulian lingkungan dipengaruhi beberapa faktor, yaitu pendidikan , umur, jumlah anggota rumah tangga, pengetahuan tentang lingkungan, sikap terhadap lingkungan, dan status perkawinan (Pusat Pengelolaan Ekoregion Jawa Kementerian Lingkungan Hidup).

Salah satu faktor yang berpengaruh dalam rendahnya perilaku masyarakat terhadap lingkungan hidup adalah kurangnya pendidikan tentang lingkungan hidup. Pendidikan merupakan salah satu aspek penting dalam perlindungan dan dalam mencegah terjadinya kerusakan lingkungan hidup. Perlindungan dan pengelolaan lingkungan hidup dengan menggunakan jalur pendidikan mempunyai kedudukan yang strategis mengingat lingkungan dan pendidikan adalah dua hal yang tidak bisa dipisahkan. Sekolah sebagai lingkungan pendidikan dan pendidikan tentang lingkungan sangat berpengaruh dalam 
memberikan peran langsung dalam menumbuhkan kecintaan para peserta didik untuk turut serta dalam mengelola dan melindungi lingkungan hidup.

Hampir di seluruh negara upaya untuk mendorong masyarakat untuk memulai gaya hidup ramah lingkungan sudah dilakukan dengan memasukkan pendidikan tentang lingkungan hidup dalam proses belajar mengajar di sekolah. Hal tersebut dilakukan agar para peserta didik mendapatkan pengetahuan di bidang lingkungan hidup, selain itu peserta didik dapat memprakktikan gaya hidup yang ramah lingkungan baik di sekolah maupun di masyarakat. Pengelolaan lingkungan hidup yang diharapkan mampu menjadi faktor pengendali Diharapkan melalui kegiatan ini akan dihasilkan beragam media yang kreatif dan menarik yang dapat digunakan pada proses pembelajaran di lembaga pendidikan anak usia dini. Upaya untuk melindungi dan mengelola lingkungan hidup harus ditanamkan sejak dini dalam lingkungan pendidikan. Sejak kecil peserta didik harus dikenalkan dengan pendidikan lingkungan hidup.

Pendidikan ramah lingkungan merupakan usaha nyata manusia yang teratur dan terencana dalam menyelamatkan lingkungan hidup. Pendidikan ramah lingkungan sangat penting untuk diterapkan dan diajarkan di lingkungan sekolah dengan tujuan agar peserta didik nantinya menjadi manusia yang peduli terhadap alam dan lingkungan. Penerapan pendidikan ramah lingkungan di sekolah akan menciptakan sekolah yang ramah lingkungan. Sekolah ramah lingkungan akan menciptakan perilaku warga sekolah yang peduli terhadap alam dan lingkungannya. Lingkungan hidup dan pendidikan merupakan dua hal yan tidak bisa dipisahkan, keduanya saling mempengaruhi satu sama lain. Manusia tidak bisa hidup tanpa lingkungan yang sehat, oleh karena itu pendidikan akan pentingnya mengelola dan melindungi lingkungan hidup sangat dibutuhkan. Kementerian Lingkungan Hidup dan Kementerian Pendidikan Nasional bekerjasama dalam upaya perlindungan dan pengelolaan lingkungan hidup. Pemberian pendidikan tentang lingkungan hidup di Indonesia tertuang dalam program Pendidikan Lingkungan Hidup (PLH) yang dilaksanakan di sekolah-sekolah mulai dari Sekolah Dasar hingga Sekolah Menengah dan kejuruan.

Dari pengertian diatas maka dapat disimpulkan bahwa lingkungan hidup adalah kesatuan ruang yang ditempati makhluk hidup bersama benda hidup dan tidak hidup termasuk manusia dan perilakunya yang dapat mempengaruhi alam, kelangsungan perikehidupan, dan kesejahteraan manusia serta makhluk hidup lainnya. Lingkungan hidup dan pendidikan merupakan dua hal yang saling berkaitan, oleh karena itu pemberian pendidikan tentang perlindungan dan pengelolaan lingkungan hidup diberikan sejak dini kepada peserta didik melalui Pendidikan Lingkungan Hidup (PLH).

Pelatihan digunakan untuk membentuk hubungan yang kuat dengan alam. Guru dilatih untuk mampu menggunakan pengajaran yang efektif, memiliki inisiatif untuk memasukkan pendidikan lingkungan ke dalam program pengajaran yang ada di sekolah. Melalui pendidikan lingkungan hidup maka akan terbentuk sekolah ramah lingkungan.

Untuk mewujudkan sekolah yang peduli dan berbudaya lingkungan maka diperlukan kebijakan-kebijakan sekolah yang sesuai dengan prinsip-prinsip dasar program Adiwiyata. Pengembangan kebijakan sekolah yang diperlukan yaitu:

(1) Visi dan Misi sekolah yang peduli dan berbudaya lingkungan

(2) Kebijakan sekolah dalam mengembangkan pembelajaran pendidikan lingkungan hidup.

(3) Kebijakan peningkatan SDM (tenaga kependidikan dan non kependidikan) di bidang pendidikan lingkungan hidup. 
(4) Kebijakan sekolah dalam upaya penghematan sumber daya alam.

(5) Kebijakan sekolah yang mendukung terciptanya lingkungan sekolah yang bersih dan sehat.

(6) Kebijakan sekolah untuk pengalokasian dan penggunaan dana

Sarana prasarana di sekolah sangat dibutuhkan untuk mewujudkan sekolah yang peduli lingkungan. Pengelolaan dan pengembangan sarana tersebut yaitu:

(1) Pengembangan fungsi sarana pendukung sekolah yang ada untuk pendidikan lingkungan hidup.

(2) Peningkatan kualitas pengelolaan lingkungan di dalam dan di luar kawasan sekolah.

(3) Penghematan sumberdaya alam (air, listrik) dan ATK.

(4) Peningkatan kualitas pelayanan makanan sehat.

(5) Pengembangan sistem pengelolaan sampah.

Lingkungan memiliki pengaruh yang cukup besar bagi keberhasilan belajar siswa, kemampuan siswa yang baik bila tidak didukung dengan lingkungan yang kondusif untuk belajar, maka akan sulit untuk mencapai tujuan pembelajaran yang maksimal. Bila lingkungan sekolah kondusif dan mendukung untuk melakukan proses pembelajaran, maka hal itu sangat membantu siswa dalam mencapai tujuan pembelajaran.

Lingkungan sekolah yang sehat akan menciptakan sekolah sehat yang dapat membangun kesehatan peserta didik baik melalui kesehatan jasmani maupun rohani, melalui pemahaman, kemampuan dan tingkah laku, sehingga siswa bisa mengambil keputusan yang terbaik untuk kesehatan mereka. Proses belajar mengajar di sekolah memerlukan ruang dan lingkungan pendukung untuk dapat membantu siswa dan guru berkonsentrasi dalam belajar. Pendidikan ramah lingkungan merupakan usaha nyata manusia yang teratur dan terencana dalam menyelamatkan lingkungan hidup sebagai tempat tinggal, mempertahankan hidup, dan meneruskan keturunan. Pendidikan ramah lingkungan merupakan sebuah konsep hidup yang bersinergis antara manusia dengan alam (Pendidikan Ramah Lingkungan dan Pendidikan untuk Semua, 2009, diakses dari http://sumberilmu.info/).

Isi Pendidikan Ramah Lingkungan yaitu:

a) Menyadarkan manusia, bahwa manusia tidak bisa hidup tanpa alam, dalam memanfaatkan sumber daya alam manusia tidak harus merusaknya.

b) Menanamkan sikap menghargai keseimbangan makro kosmos bumi, yaitu bahwa segala benda dan makhluk yang tercipta di bumi adalah saling melengkapi untuk menjaga keseimbangan alam semesta.

c) Tidak merusak ekosistem bumi, misalnya dengan mengolah sampah organik dan non-organik menjadi barang yang bermanfaat, sehingga tidak merusak ekosistem tanah dan air.

Pendidikan ramah lingkungan sangat penting untuk diterapkan dan diajarkan di lingkungan sekolah dengan tujuan agar peserta didik nantinya menjadi manusia yang peduli dan peka terhadap alam dan lingkungan sekitarnya. Pendidikan ramah lingkungan juga bertujuan untuk membantu peserta didik dalam memperoleh pengertian dasar tentang bagaimana fungsi lingkungan serta bagaimana cara menjaga dan mengelolanya. 
Konsep 3R diterapkan dalam mewujudkan sekolah ramah lingkungan. Konsep 3R terdiri dari Reduce (mengurangi), Reuse (menggunakan kembali), Recycle (mendaur ulang), berikut ini dijelaskan tentang konsep 3R:

1) Reduce Reduce atau pengurangan merupakan kegiatan mengurangi pemakaian atau pola perilaku yang dapat mengurangi produksi sampah serta tidak melakukan pola konsumsi yang berlebihan.

2) Reuse Reuse atau penggunaan kembali merupakan kegiatan menggunakan kembali material atau bahan yang masih layak pakai.

3) Recycle Recycle atau mendaur ulang merupakan kegiatan mengolah kembali atau mendaur ulang. Kegiatan ini memanfaatkan barang bekas dengan cara mengolah materinya untuk dapat digunakan lebih lanjut

\section{METODE}

Kegiatan ini dilakukan dalam bentuk pelatihan dan pendampingan dengan melibatkan mitra sasaran yaitu TK Salsa di Desa Cinta Rakyat, Kecamatan Percut Sei Tuan, Kabupaten Deli Serdang, yang meliputi tahap persiapan dan perencanaan, pelaksaan, pemantauan dan evaluasi. Dalam menyampaikan materi, media, dan metode yang digunakan adalah:

\section{Bercakap-cakap}

Bercakap-cakap digunakan tim pelaksana mulai dari tahap pra survei, perencanaan kegiatan, dan pelaksanaan.

> Pada tahap pra survei, bercakap-cakap digunakan untuk menemukan kendala yang dialami oleh guru-guru PAUD di Desa Cinta Rakyat baik pada saat proses belajar mengajar mau pun di luar proses belajar mengajar. Dengan dilakukan bercakap-cakap ini, ketua tim pelaksana dengan mitra, yaitu TK Salsa dapat membuat suatu kesepakatan bersama.

$>$ Pada tahap perencanaan dan pelaksanaan, metode bercakap-cakap dipergunakan baik antara personil tim pelaksana maupun antara tim dengan pengelola TK Salsa sebagai mitra. Dalam tim bercakap-cakap dipergunakan untuk merencanakan kegiatan yang akan dilakukan, membagi tugas untuk masing-masing personil tim, melaksanakan kegiatan. Sedangkan, bercakap-cakap yang dilakukan terhadap pengelola PAUD/TK adalah untuk merencanakan langkah-langkah perencanaan program kegiatan hingga akhir program kegiatan.

\section{Pelatihan dan Pendampingan}

Pelatihan dan pendampingan diberikan kepada para guru TK Salsa untuk menciptakan sekolah yang ramah lingkungan bagi anak usia dini.

\section{Praktek}

Guru-guru mitra dalam sekolah binaan akan mempraktekkan secara langsung tentang sekolah yang ramah lingkungan. Hasil dari kegiatan praktek ini nantinya berupa media pembelajaran anak usia dini serta dokumentasi.

Tahapan-tahapan yang dilaksanakan dalam pelatihan ini terbagi atas:

\section{a) Tahap Persiapan}

Tahap persiapan dan perencanaan dilakukan koordinasi dengan pihak Lembaga Pengabdian Masyarakat (LPM) UNIMED dengan berbagai pihak, terutama untuk menentukan lokasi kegiatan dan jadwal pelaksanaan kegiatan. Tim pelaksana kegiatan mempersiapkan bahan-bahan dan peralatan yang akan diperlukan, pendistribusian tugas masing-masing anggota dan persiapan ke lapangan serta pembuatan kisi-kisi evaluasi yang akan dipergunakan pada saat pemantauan kegiatan. 


\section{b) Tahap Pelaksanaan}

Tahap pelaksanaan pelatihan dan pendampingan yang akan dilakukan dalam upaya menciptakan lingkungan sekolah yang nyaman bagi anak usia dini untuk meningkatkan kompetensi pedogik guru di TK Salsa, Desa Cinta Rakyat, Kabupaten Deli, Provinsi Sumatera Utara.

\section{HASIL DAN DISKUSI}

Kegiatan pengabdian ini dimulai dengan mencari informasi mengenai Pendidikan Anak Usia Dini (PAUD) yang memerlukan bantuan pendampingan. Setelah mendapatkan data Taman Kanak-kanak (TK), maka dilakukan pertemuan sekaligus sosialisasi kepada Sekolah/TK mitra. Wawancara yang dilakukan saat kegiatan sosialisasi menunjukkan bahwa pihak sekolah yang diwakili oleh Kepala Sekolah menyambut baik kegiatan yang akan dilakukan. Selanjutnya, dilakukan penandatanganan kontrak sebagai legalitas kegiatan yang akan dilakukan. Didalamnya memuat hak dan kewajiban sekolah sebagai pihak kedua dan ketua pengabdian mewakili tim pengabdian sebagai pihak kedua. Adapun hasil kegiatan pengabdian ini akan diuraikan sebagai berikut:

\section{Kegiatan Persiapan}

1.1 Persiapan Mekanisme pelaksanaan kegiatan Pengabdian meliputi tahapan berikut ini:

(1) Penyiapan dan Survei lokasi Pengabdian

(2) Koordinasi dengan pemerintah Kelurahan dan Kecamatan kegiatan Pengabdian

(3) Perekrutan mahasiswa peserta Pengabdian kerjasama dengan LPM UNIMED

(4) Pembekalan dan pengasuransian mahasiswa peserta pengabdian

(5) Penyiapan sarana bantuan dalam kegiatan pelatihan pembuatan media.

\subsection{Jadwal dan Materi Pembekalan}

Jadwal dan Materi pembekalan mahasiswa mencakup teori dan pratek beberapa aspek,disesuaikan dengan jadwal dan materi Pembekalan dari Panitia.

\section{Pelaksanaan Pelatihan}

Pada tahap ini, setelah mahasiswa ditempatkan di lokasi, Dosen Pembimbing menyelenggarakan Bimbingan Teknik tentang Kegiatan Pilot Proyek Pemutakhiran Data Program Kartu Sejahtera berbasis Partisipasi Masyarakat. Dalam kegiatan ini sekaligus menghadirkan masyarakat sebagai peserta Bimtek. Hal ini bertujuan agar sejak awal sudah terjadi interaksi antara mahasiswa dan masyarakat sebelum pelaksanaan kegiatan pilot proyek dilaksanakan. Adapun materi bimbingan teknik adalah sebagai berikut :

1) Hakikat dan Jenis Media Pembelajaran.

2) Penyesuaian Media yang Digunakan dalam Lembaga PAUD

3) Pelatihan Pembuatan Media

Pelaksanaan Kegiatan

a. Bimbingan Teknik Pelatihan Pembuatan Media Pembelajaran Kreatif dan Menarik. Kegiatan ini dilaksanakan pada minggu pertama saat mahasiswa berada di lokasi.

b. Persiapan Jenis Media yang akan dibuat. Kegiatan ini dilaksanakan pada minggu kedua.

c. Kegiatan Pelatihan Pembuatan Media. Kegiatan ini dilaksanakan pada minggu ketiga dan kelima. 
d. Kegiatan Menciptakan Media yang Kreatid dan Menarik untuk Anak. Kegiatan ini dilaksanakan pada minggu keenam.

e. Evaluasi media yang dihasilkan. Kegiatan ini dilaksanakan pada minggu ketujuh.

f. Pembuatan laporan. Kegiatan ini dilaksanakan pada minggu kedelapan.

Kegiatan seminar dan pelatihan pembuatan media pembelajaran anak berbasis kreativitas ini ditujukan untuk orang tua dan guru-guru PAUD dan guru-guru SD. Tujuan seminar dan pelatihan pembuatan media pembelajaran anak berbasis kreativitas ini untuk peningkatan kreativitas guru atau pendidik dalam membuat media pembelajaran dengan memanfaatkan media daur ulang, barang-barang bekas dengan nilai edukatif. Seperti media pembelajaran playdough, finger painting, boneka wisuda, kreasi kokuru, kreasi origami dan lainnya. Hal ini dimaksudkan agar pendidik tidak kesulitan dalam menjelaskan tema yang sedang diajarkan. Dengan adanya media pembelajaran ini guru atau pendidik akan dimudahkan dalam proses pembelajaran, dan hasil dari kegiatan seminar sekaligus pelatihan.

\section{KESIMPULAN}

Kegiatan ini merupakan pilot proyek untuk menjadi acuan dalam pembuatan media pembelajaran yang dapat digunakan dalam proses belajar anak usia dini di Kabupaten Deli Serdang. Pelaksanaan pelatihan ini mendukung penyediaan media yang dapat digunakan dalam proses belajar anak usia dini, sehingganya diyakini bahwa pelatihan seperti pembuatan media ini akan terus berlanjut guna mendukung pembelajaran dan proses pengembangan kecerdasan anak pada setiap lembaga PAUD yang berada di Kabupaten Deli Serdang.

Perlu adanya pelatihan pembuatan media secara berkelanjutan dari pihak UNIMED bekerjasama dengan Dinas Pendidikan Kecamatan Percut Sei Tuan Kabupaten Deli Serdang. Perlunya kerjasama yang berkolaborasi tersebut agar semua guru TK di Kabupaten Deli Serdang memiliki persepsi yang sama dalam membuat APE yang ramah lingkungan.

\section{DAFTAR RUJUKAN}

Eliason,Loa Jenkins.(1994).A partical Guide to Early Childhood Curriculum.

Usman (2000). Menjadi Guru Profesional. Bandung: Rosda Karya.

Wau, Yasaratodo. (2016). Profesi Pendidikan. Diktat Perkuliahan Universitas Negeri Medan. 